MAAILMALLA

\title{
Henkilöstön kehittämisen tutkimusta ja käytäntöä
}

\author{
The Academy of Human Resource Development perustettiin vuonna 1993 USA:ssa. Järjestö \\ edistää HRD:n, henkilöstön kehittämisen, teorioiden ja käytänteiden systemaattista \\ tutkimusta ja tutkimustulosten soveltamista, välittää tietoa HRD:stä ja tarjota \\ mahdollisuuksia kokemusten vaihtoon. Järjestö pyrkii monitieteisyyteen ja \\ kansainvälisyyteen. Kirjoittaja osallistui helmi-maaliskuun taitteessa järjestön \\ konferenssiin Yhdysvalloissa.
}

Academy of Human Resource Development järjesti kolmannen vuosittaisen konferenssinsa keväällä Minneapolisissa USA:ssa. Konferenssiin osallistui noin 250 alan tutkijaa, opettajaa ja henkilöstön kehittäjää. järjestelyistä vastasivat yhteistyössä Minnesotan ja St. Thomasin yliopistot. Aikoinaan paljon pohjoismaisia maahanmuuttajia houkutellut Minneapolis tarjosi varsin kotoisan kevättalviset puitteet konferenssille. Alkuvuoden -50 celsiuksen pakkasista muistutti enää teksti t-paidassa: "I survived the Minnesota cold!".

Konferenssin pääteema oli "Performance with Integrity". Integrity-termi kääntyy Oxfordin englanninkielen sanakirjan mukaan rehellisyydeksi, luotettavuudeksi, lahjomattomuudeksi ja eheydeksi eli konferenssissa pohdittiin erityisesti HRD:n teorian ja käytännön etiikkaa ja näiden yhdenmukaisuutta käytännön toiminnassa. Ydinkysymys on, missä määrin henkilöstön kehittäjä voi toimia kuten opettaa eli miten organisaation tavoitteet edistävät tai estävät henkilöstön kehittämistä nimenomaan ihmis- ja kehittämislähtöisistä näkökulmista, jotka muodostavat HRD-etiikan perustan.

Yhden konferenssin avauspuheenvuoroista käyttäneen Ronald L. Jacobsin sanoin HRD-toiminta on harvoin yhtä selkeätä ja yksiselitteistä, kuin teorioiden mukaan voisi olettaa. Erilaiset organisaatiot ovat HRD-toiminnalle moniselitteisiä toimintaympäristöjä, joissa samat asiat saavat eri merkityksiä näkökulmasta riippuen. Tällaisissa toimintaympäristöissä HRD-toiminnan luotettavuudella ja yhdenmukaisuudella on tärkeä merkitys. HRD:n luotettavuus koostuu toimintaa ohjaavien eettisten arvojen ja sääntöjen yhdenmukaisuudesta ja siitä, miten nämä eettiset arvot todentuvat HRD-toiminnassa eli miten ja mitä tarkoitusta varten henkilöstön kehittämistä toteutetaan.

Victoria J. Marsick Columbian yliopistosta pohti sitä, miten henkilöstön kehittäjät kokevat tilanteet, joissa he joutuvat henkilöstön kehittäjinä toimimaan vastoin omia eettisiä käsityksiään, esimerkiksi olemaan "johtajana" päättämässä työntekijöiden irtisanomisista ja sarnalla edustamaan henkilöstöä. Marsick totesikin, että henkilöstönkehittäjillä ei ole vielä olemassa yhteisiä eettisiä käyttäytymissääntöjä tai toimintaperiaatteita, jotka ohjaisivat yhdenmukaiseen ja luotettavaan käytäntöön. Koska kyse on nimenomaan aikuisten ihmisten kehittämisestä, yhdeksi perustaksi eettisen koodiston laatimiselle Marsick ehdotti tukeutumista erityisesti aikuisia kuvaaviin kehitysteorioihin. Erityisesti hän mainitsi Keganin ja Torbertin tutkimukset, jotka kohdistuvat mm. aikuisten työtä koskeviin käsityksiin ja johtajien toimintaan, sekä niiden pohjalta luodut kehitysvaiheet.

Alustajiksi (keynotes-puheenvuorojen pitäjiksi) oli kutsuttu eri yrityksiä edustavia henkilöitä, jotka omassa toimitusjohtajan, konsultin tai koulutuspäällikön työssään vastaavat henkilöstön kehittämisestä yrityksessään. Konferenssin pääosan muodostivat 34 symposiumia laajalla aihevalikolla. Symposiumien aiheissa näkyi selvästi HRD:n kaksi vallitsevaa trendiä eli yksilön, ryhmien ja organisaation taitojen ja tietojen kehittäminen suorituskyvyn ja -tason parantamiseksi (performance improvement) ja henkilöstön tietojen ja 
taitojen kehittäminen edistämällä yksilön, ryhmien ja organisaation oppimista ja oppimistaitoja (learning organization, action learning). Huomattavana kiinnostuksen kohteena näyttivät olevan myös työn ja oppimisen yhdistäminen ja mahdollisuudet soveltaa opitut asiat työhön. Symposiumeissa keskityttiin myös henkilöstön kehittäjien rooleihin työelämässä ja työn teoreettisiin perusteisiin ja toisaalta alan akateemiseen koulutukseen yliopistojen HRD-ohjelmissa.

Niin USA:laisten kuin myös suomalaisten tutkijoiden suuren mielenkiinnon kohteena oleva oppiva organisaatio ja sen problematiikka näyttää olevan yksi HRD-tutkimuksen avainalue. Aiheesta kiinnostuneet tutkijat näyttävät painivan samanlaisten kysymysten parissa kuin täälläkin: Kun organisaation oppimista ei voi olla olemassa ilman yksilön oppimista, kuinka yksilön oppiminen voidaan yhdistää organisaation oppimiseen ja kuinka yksilön, ryhmien ja organisaation oppimista voidaan yleensä arvioida? Mitä mitataan, kun halutaan tietää, onko organisaatio oppiva?

Viimeksi mainittuun kysymykseen oli etsitty vastausta eräässä autotehtaan kehittämisprojektissa (Bierema \& Beredish 1996). Organisaation oppiminen oli mielenkiintoisella tavalla operationaalistettu yksilön tasolla mm. kriittisen reflektiivisyyden, henkilökohtaisen hallinnan ja oppimisen siirtovaikutuksen arvioimiseksi, ryhmän tasolla mm. dialogin, työpaikan ihmissuhteiden ja tuotantolinjojen kehittymiseksi sekä organisaatiotasolla mm. itseohjatun oppimisen ja uusien tietojen ja taitojen hyödyntämisen arvioimiseksi. Projektin tulokset osoittivat myönteistä kehittymistä edellä mainituissa piirteissä.

\section{Asiantuntijaksi oppiminen}

Yksi symposiumeista keskittyi asiantuntijuuteen organisaatioissa. Tutkimusintressit tällä alueella näyttävät olevan yhdensuuntaisia kirjoittajan oman viiteryhmän, kasvatustieteiden tutkimuslaitoksen asiantuntijaksi oppimisen tutkimusryhmän, työn kanssa. Asiantuntijuuden ja sen kehittymisen tarkastelusta on kehittymässä myös yksi HRD:n avainalueista. Siitä, miten asiantuntijuutta voisi määritellä ja tutkia, ei ole olemassa selkeätä ja yhdenmukaista käsitystä.

Näyttää kuitenkin siltä, että asiantuntijuuden tarkastelu keskittyy vielä korkeatasoisen tai erinomaisen suorituksen ja siinä tarvittavien taitojen tutkimiseen ja määrittelyyn. Tämä perustuu kognitiiviseen asiantuntijuuden tutkimukseen, joka on keskittynyt $\mathrm{mm}$. siihen, mitä asiantuntijat tekevät, miten he sen tekevät, millainen on asiantuntijatasoinen suoritus ja miten eksperttiasiantuntija eroaa suoritukseltaan noviisista. Henkilöstön kehittämisen perustana olevaan asiantuntijuuden tutkimukseen liittyy kiinteästi työhön liittyvien suoritustavoitteiden arvioiminen ja mittaaminen sekä yksilön että organisaation näkökulmasta. Mielenkiintoisen näkökulman asiantuntijuussymposiumiin toi yksilöllisen asiantuntijuuden sosiaalisen rakentumisen tarkastelu (Gleespan 1996).

Kirjallisuuden perusteella näyttää siltä, että yksilön asiantuntijuuden kehittymisen kannalta on tärkeä merkitys sillä tuella, jota henkilö saa muilta saman alan asiantuntijoilta. On eduksi, jos voi työskennellä sellaisten asiantuntijoiden ohjauksessa, jotka itsekin ovat omistautuneet itsensä ja oman alansa kehittämiselle ja jotka ovat valmiita auttamaan ja jakamaan tietämystään. Tämän toteamuksen valossa esimerkiksi Suomessa käyty viimeaikainen keskustelu jatko-opintojen ja tutkijakoulutuksen ohjauksen tärkeydestä tulee entistä merkityksellisemmäksi.

Mielenkiintoinen yksityiskohta oli eräässä symposiumissa esitelty tutkimus (Peterson \& Provo 1996), joka kohdistui USA:n yliopistoissa toimivien aikuiskasvatuksen ja HRD:n opetusta järjestävien laitosten ja koulutusohjelmien ominaispiirteiden ja toimintaedellytysten ja niiden välisten yhtäläisyyksien ja erojen tutkimiseen. Tutkimuksen alustavien tulosten mukaan aikuiskasvatuksen ja HRD:n laitokset ovat profiileiltaan varsin samanlaisia, ainoastaan iän, virkojen ja palkkauksen suhteen näyttää löytyvän eroja. Aikuiskasvatuksen laitoksien henkilökunnan keski-ikä näyttää olevan korkeampi, professuurien ja apulaisprofessuurien määrä suurempi ja palkkauksen taso korkeampi. Mielenkiintoista kuitenkin oli, että 
HRD-laitokset näyttivät ansaitsevan palkkarahojaan enemmän myös ulkopuolisista lähteistä, kuten konsultoinnista. Huomattavaa oli, että laitoksien välille oltiin suunnittelemassa tai perustamassa useita yhteistyösuhteita eli näiden kahden alan jonkinasteista integroitumista oli havaittavissa.

Aikuiskasvatuksen ja HRD-opetuksen sijoittuminen erillisiin laitoksiin eroaa omasta tilanteestamme. Meillähän henkilöstön kehittäminen ja aikaisemmin henkilöstökoulutus on pitkään nähty yhtenä osana (työelämän) aikuiskoulutusta, ja se on luonnollisesti sijoittunut pääosin aikuiskasvatuksen tutkimus- ja opetuskenttään, vaikka samankaltaisia sisältöjä löytyy myös talous- ja hallintotieteistä. Alojen erillisyyteen USA:ssa on saattanut johtaa perinteinen käsitys, jonka mukaan aikuiskoulutus ja HRD ovat erillisiä aloja ja henkilöstön kehittäjää ei voida määrittää aikuiskouluttajaksi, koska henkilöstön kehittämisessä on kyse nimenomaan työnantajan asettamien oppimistavoitteiden saavuttamisesta. Nyttemmin tätä näkemystä ovat muuttaneet niin. käsitykset yksilön ja organisaation tavoitteiden integroimisesta, työssä oppimisesta ja organisaation oppimisesta. Muutos lienee nähtävissä myös mainitun tutkimuksen tuloksissa.

\section{Euroopan ja Amerikan vuoropuhelu}

Eurooppalaisena ja suomalaisena konferenssissa mukanaolo oli kiintoisa ja antoisa kokemus. Symposiumit tarjosivat hyvän läpileikkauksen henkilöstön kehittämisen sekä käytännöstä että tutkimuksesta erityisesti USA:ssa. Konferenssissa oli selvästi havaittavissa isäntämaan kollegojen kiinnostus eurooppalaista käytäntöä ja tutkimusta kohtaan. Kansainvälistyminen ei siis ole haaste ainoastaan meille suomalaisille. Järjestön pyrkimys kansainvälistymiseen näkyi myös erikoistunnustuksissa kansainvälisyyden edistämisestä, joita tänä vuonna myönnettiin Martin Mulderille Twenten yliopistosta, Hollannista ja Rod McDonaldille Australiasta.

Uskoisin, että suomalaisillakin työelämän aikuiskoulutuksen tutkijoilla voisi olla hyvät mahdollisuudet edistää alan tutkimusta ja käytäntöä järjestön kautta.

\section{Tietoja järjestön toiminnasta}

Academy of Human Resource Development -järjestössä on noin 500 jäsentä, joista kutakuinkin puolet on opiskelijoita. Järjestöön kuuluu sekä alan opettajia ja tutkijoita että käytännön henkilöstön kehittämistyössä toimivia. Toistaiseksi enemmistö jäsenistä on USA:sta, mutta esimerkiksi Twenten yliopisto Hollannista on ollut aktiivisesti mukana konferensseissa. järjestön uusi presidentti on tästä vuodesta alkaen professori Richard A. Swanson Minnesotan yliopistosta. Ennen häntä presidenttinä ovat toimineet Karen E. Watkins ja R. Wayne Pace. Järjestö jakaa vuosittain tunnustuspalkinnon alan ansioituneelle edustajalle. Tänä vuonna palkinnon sai Victoria J. Marsick. Seuraavat vuosittaiset konferenssit järjestetään 1997 Atlantassa, 1998 Chicagossa ja 1999 Amsterdamissa.

Jäsenyys oikeuttaa Human i Resorce Development Quarterly -lehteen. Tämä referee-lehti on ilmestynyt vuodesta 1990 lähtien ja se on alunperin ASTD:n (American Society of Training and Development) tutkimuskomitean ja Minnesotan yliopiston Koulutuksen ja kehittämisen koulutusohjelman käynnistämä ja Jossey-Bassin julkaisema. Nykyisin artikkelien hyväksymisprosentti on noin 30. Lehdellä on tärkeä rooli HRD-alan sekä tutkimuksen että käytännön kehittymisen edistämisessä ja näiden kahden välisen vuoropuhelun ylläpitämisessä. lisäksi järjestö tiedottaa ajankohtaisista asioista jäsentiedotteessaan, "Forumissa".

Mainitsematta ei voi myöskään jättää konferenssijulkaisua, "AHRD 1996 Conference Proceedings", johon kerätään kaikki konferenssin symposiumeissa esitetyt paperit kokonaisuudessaan. Tämä tänäkin vuonna yli 700 sivuinen julkaisu, mahdollistaa perehtymisen hyvin laajasti alan ajankohtaiseen tutkimukseen, koska itse konferenssissa eri symposiumien välillä on pakko valikoida. Kaikki tutkimukset, joihin tässä artikkelissa on viitattu löytyvät konferenssijulkaisusta. 


\section{Lähde}

Academy of Human Resource Development 1996 Conference Proceedings. Minneapolis, Minnesota February 29 - March 3 , 1996. Elwood F. Holton (ed.). Austin: Academy of Human Resource Development.

\section{Lisätietoja}

The Academy of Human Resource Development, 8140 Burnet Road, P.0. Box 9598, Austin, Texas 78766, USA, puh. 512-32-2736, fax 512-371-7449, Lisätietoja myös kirjoittajalta, Jyväskylän yliopiston kasvatustieteen laitos, puh. 014-601672, e-mail tvalkeav@dodo.jyu.fi.

Tuija Valkeavaara 